\title{
Dimensional Analysis of All Units on Intergovernmental Relations Within the Mining Authority (Study on Unlicensed Gold Mining in District of Kuantan Singingi)
}

\author{
Khotami ${ }^{1)}$, Nandang Alamsah Deliarnoor ${ }^{2)}$, Utang Suwaryo ${ }^{3)}$, Neneng Yani \\ Yuningsih ${ }^{4}$ \\ Lecturer at the Governmental Science, Faculty of Social and Political Sciences, Riau Islamic University, \\ Pekanbaru, Indonesia ${ }^{1)}$ \\ Professor on Government Studies, Universitas Padjadjaran, Bandung, Indonesia ${ }^{2)}$ \\ Professor on Government Studies, Universitas Padjadjaran, Bandung, Indonesia ${ }^{3)}$ \\ Lecturer at the Department of Government Studies, Universitas Padjadjaran, Bandung, Indonesia ${ }^{4}$ \\ khotami.ip@soc.uir.ac.id
}

\begin{abstract}
This research is located in Kuantan Singingi Regency which is motivated by the busy activities of gold mining without permits (PETI) carried out by the local community. This is driven by promising income so that these activities are used as a livelihood and a lack of public awareness of the dangers of PETI. In addition, the low level of involvement of government actors and community participation has an impact on the weakness of regulations that form the legal basis for mining activities. This study looks at the relationship between government units that work together in managing gold mining based on their authority. The informants of this study were employees of the Riau Province ESDM Service, members of the Riau DPRD, Kuantan Singingi District Polres staff, DLH employees of Kuantan Singingi Regency and the community. The technique of determining the informants was carried out by purposive method by digging in-depth information according to the characteristics of the study. The data collection technique is done by interview, observation and documentation. The data analysis technique was used by applying a qualitative narrative approach that conveyed the results of the analysis related to PETI. The results of the study found that the importance of local regulations on community mining that involves both provincial and district governments. The weakness of the legal regarding the implementation of gold mining activities must be strengthened by coordinative efforts and cooperation between the provincial government, DPRD and district governments by sharing the perceptions, ideas of each actor.

Keywords: All Units, Authority, Mining
\end{abstract}

\footnotetext{
Abstrak. Penelitian ini bertempat di Kabupaten Kuantan Singingi yang dilatarbelakangi oleh ramainya aktivitas pertambangan emas tanpa izin (PETI) yang dilakukan oleh masyarakat setempat. Hal ini didorong oleh penghasilan yang menjanjikan sehingga kegiatan tersebut dijadikan sebagai mata pencaharian dan kurangnya kesadaran masyarakat akan bahaya PETI. Selain itu, rendahnya tingkat keterlibatan aktor pemerintah dan partisipasi masyarakat, berdampak terhadap lemahnya aturan yang menjadi dasar hukum kegiatan pertambangan. Penelitian ini melihat bagaimana hubungan antar unit pemerintah yang bekerjasama dalam mengelola pertambangan emas berdasarkan kewenangan yang dimiliki. Informan penelitian ini yakni meliputi pegawai Dinas ESDM Provinsi Riau, anggota DPRD Riau, Pegawai Polres Kabupaten Kuantan Singingi, Pegawai DLH Kabupaten Kuantan Singingi serta masyarakat. Teknik penentuan informan dilakukan dengan cara purposive dengan menggali informasi secara mendalam sesuai dengan karakteristik penelitian. Teknik pengumpulan data dilakukan dengan wawancara, observasi dan dokumentasi. Teknik analisis data yang digunakan dengan menerapkan pendekatan narasi kualitatif yang menyampaikan hasil analisis berkaitan dengan PETI. Hasil penelitian mendapati bahwa pentingnya peraturan daerah tentang pertambangan rakyat yang melibatkan pemerintah baik provinsi maupun kabupaten. Lemahnya payung hukum tentang pelaksanaan kegiatan pertambangan emas harus diperkuat dengan upaya koordinatif dan kerjasama antara pemerintah provinsi, DPRD dan pemerintah kabupaten melalui penyamaan persepsi, ide dari masing-masing aktor. Kata Kunci: All Units, Kewenangan, Pertambangan
} 


\section{INTRODUCTION}

Indonesia is a country that has a wealth of natural resources including land and water and even has natural products in the form of mining materials, in the form of gold, silver, copper, oil and gas, coal, diamonds and other mining products which are fully controlled by the state. Of course, the results of natural wealth controlled by the state must be managed in order to improve the standard of living and welfare of all the people. The government has authority, among others, in terms of making policies and laws and regulations as well as establishing a mining licensing system. Regulations regarding mining in Indonesia are actually regulated in Law Number 4 of 2009 concerning Mineral and Coal Mining. This Law regulates the authority possessed by each level of government in terms of mining management, from the central government to local governments.

After the issuance of Law Number 23 of 2014 concerning Regional Government, there has been a paradigm shift in the administration of government authority related to natural resource management, including the mineral and coal mining sector which is shared between the central government and local governments. The provincial government in this case has the authority to issue mining business permits (IUP) for metal and nonmetal minerals in accordance with the 7 (seven) pieces of authority held by the provincial government in the mineral and coal sub-sector. Meanwhile, the district government after the enactment of the Regional Government Law does not have the authority in mineral and coal mining.

With regard to mining, the potential for gold mining in Riau Province is in one area, namely in Kuantan Singingi Regency. But unfortunately, this potential has not been well managed by the local government through legal regulations regarding community mining area permits so that the gold products are illegally explored by the community without any permission from the government. Gold mining activities without a permit (PETI) in Kuantan Singingi Regency have occurred since early 2008. Environmental pollution, soil damage due to excavation of PETI activities in a number of areas in Kuantan Singingi Regency is a negative impact of mining, where the problem basically originates from a lack of awareness miners of the importance of preserving the environment. So if this is not resolved immediately it will have a negative impact on the lives of the communities around the mining site in the long term. Most of the sub-districts in Kuantan Singingi Regency have PETI activities. Based on data obtained from the Kuantan Singingi Regency Government, of the 15 sub-districts in Kuantan Singingi Regency, almost part of the existing sub-districts have illegal mining practices and are experiencing land damage. The comparison of land damage due to PETI 
activities in all sub-districts in Kuantan Singingi Regency can be seen in the following graph:

Figure 1. Land Damage due to PETI Activities in Kuantan Singingi Regency

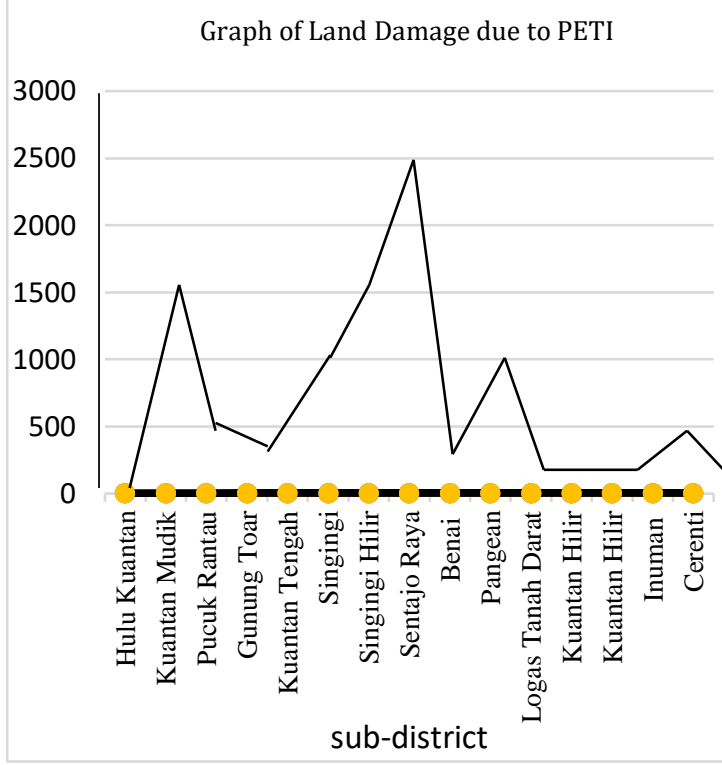

Source: Environmental Service of Kuantan Singingi Regency, 2020

Based on the data above, land damage due to gold mining activities without permission is spread across almost all districts in Kuantan Singingi Regency. This shows that almost all areas in Kuantan Singingi Regency have PETI activities that have an impact on land damage. The consequences of mining activities that are illegal in nature cause losses and problems, both for the state and for the community, compared to the benefits that can be obtained. The rise of illegal gold mining activities in a number of sub-districts in Kuantan Singingi Regency is mostly carried out by local people. The factor that affects the prevalence of gold mining activities without permits is due to the promising income so that local people make this illegal mining activity their livelihood. In addition, this condition is supported by the lack of awareness of the local community about the dangers of PETI, causing the growth of PETI to increase. This is because land owners, village officials, as well as local youths get a fee from mining activities. Another factor that also dominates is the low level of involvement of actors in the government (inside government) and community participation in policy formulation, which affects the weakness of regulatory products that serve as the legal umbrella for gold mining activities in Riau Province, so this is one of the driving factors for growth. and the development of illegal gold mining activities that are detrimental to the government and local communities. Based on this empirical description, the authors ask questions in this study, namely: How is the exercise of authority by government units in gold mining issues in Kuantan Singingi Regency, Riau Province?

The unitary state according to Cohen and Peterson can be understood as a country where the central government exercises the highest sovereignty in the country. In order for the central government to carry out its duties effectively, its activities are directly monitored and limited by law. All government units formed under the central government government must submit to the Central government in an organizational manner based 
on the prevailing laws and regulations. Fred Isjwara (1974: 188) argues that a unitary state is the strongest form of state when compared to a federal or confederation state, because in a unitary state there is union and unity. Abu Daud Busroh (1990: 64-65) states that a unitary state is a single state which means that there is no state within the state, there is only one single government, namely the central government which has the highest power and authority in the country. Meanwhile, Amrusyi, 1987: 56) sees that the unitary state has 2 forms:

a. Unitary State with a centralized system. In a unitary state with a centralized system, all affairs in the state are directly regulated by the central government, while the regions will carry out instructions from the central government.

b. Unitary State with a decentralized system. In a unitary state with a decentralized system, regions are given the authority to manage their own households (regional autonomy) which are called autonomous regions.

\section{Central Government}

The central government as a government entity is the highest government entity compared to other government entities in the Unitary State of the Republic of Indonesia. In other words, it is the highest government structure in the Republic of Indonesia as a unitary state which has the characteristic that there is only one government that is centralized in the national/central government. Meanwhile, in a unitary state, the autonomous region is not an independent government entity or as a state within a state like the one in the most orthodox federal states, this is because Indonesia is a unitary state that does not allow a state within a state (Bhenyamin, 1993).

\section{Provincial Government}

As explained above, the province is an autonomous region which is also an administrative area as the Governor's working area is given partial authority by the central government to regulate and manage government affairs and the interests of local communities based on their own initiatives that come from the aspirations of the people in the system of the Republic of Indonesia. Province is a unit of territory which is used as the name of an administrative region that is under the territory of a state or state. In its position as an autonomous region as well as an administrative region, the province is led by a Governor as an extension of the central government who is also the regional head in administering government affairs in the provincial area.

\section{District Government}

The status of the district autonomous region as well as the administrative area is the working area for the Regent in carrying out government affairs based on his own initiative in the interest of the local community which refers to the prevailing laws and regulations. 
As an affirmation, apart from having the status of a district/city, it is also an administrative area which becomes the working area for the regent/mayor in carrying out general government affairs in the regency/city area.

According to W.S Sayre (1960), in its best definition, government is an organization of the state that shows and exercises its power. Furthermore, according to David Apter (1977), the government is the most common member unit that has a certain responsibility to maintain the system that includes it and the practical monopoly regarding its coercive power (in Kencana Syafi'e, 2010).

\section{Village Government}

Village government is part of the national government whose implementation is aimed at rural areas. Village government is a process in which the efforts of the village community concerned are combined with government efforts to improve the standard of living of the community (Maria Eni Surasih, 2003: 23). Meanwhile, for village communities, the term village autonomy refers not only to village government autonomy but also to village communities' autonomy in determining themselves and managing what they have for the welfare of the village community itself.

Furthermore, Ateng Syafrudin (2000: 22) argues that there is a difference between the notions of authority and authority. We must distinguish between authority (authority, gezag) and authority (competence,

bevoegheid). Authority is what is called formal power, power that comes from the power given by law, whereas authority only concerns a certain "onderdeel" (part) of the authority. Within the authority there are powers (rechtsbe voegdheden).

Furthermore (Wasistiono, 2003: 26) provides a description of the authority that the private sector plays an important role at the distribution or production level, while the policy, standards and licensing levels are still held by the government. Meanwhile, the most important part of decentralization to nongovernment institutions is relief from government officials for various roles with the private sector and society. This is in accordance with the reflection of the new paradigm of government, namely that good governance is the one that governs the least.

According to H.D Stout, authority is the definition that comes from the law of government organizations, which can be explained as all the rules relating to the acquisition and use of governmental powers by public legal subjects in public legal relations (in Ridwan, 2013: 71). According to Bagir Manan, authority in legal language is not the same as power. Power only describes the right to do and not act. Authority at the same time means rights and obligations (Nurmayanti, 2009: 26). 


\section{RESEARCH METHODS}

The method used in this research is through a qualitative approach. The use of methods with a qualitative approach is intended to explore and deepen social symptoms and the social environment which includes actors, events, places and times. According to John W. Creswell (2016: 4), qualitative research methods are a method for exploring and understanding the meaning that some individuals or groups of people think come from social or human problems. This qualitative method is designed with certain procedures, by collecting data from informants related to the research context and then interpreting the data according to existing sources and situations. Those who became informants in this study consisted of employees of the Riau Province ESDM Service, members of the Riau DPRD, Kuantan Singingi District Police Officers, Environmental Service Employees of Kuantan Singingi Regency and the community. The technique of determining informants in the study was carried out in a purposive way, namely to dig deep information according to the characteristics of the study in certain situations and conditions. Meanwhile, in this research, data collection techniques were carried out by means of interviews, observation and documentation. Interviews were conducted with a number of competent and knowledgeable informants related to PETI activities who also observed the individual's behavior and activities at the research location. Meanwhile, the documents obtained in the research came from print and electronic media news, official documents, papers and meeting results. The data analysis technique used is based on the presentation by applying a qualitative narrative/reporting approach in conveying the analysis results related to the PETI issue.

\section{DISCUSSION}

Based on the opinion of Wright (1975: 4), the first and most important thing is that intergovernmental relations (IGR) exists in the federal state system. However, the concept of American Federalism is not the totality of the IGR. in this context the IGR can cover more than would normally be explained from the concept of federalism where the emphasis is on state relations or on relations between states. The IGR recognizes not only state and state relations, but also state, local, state and interstate relationships. In summary, IGR is a suitable object for studying all permutations and combinations in the relations between government units as well as in the federal state system. While the second term used is in public administration where it refers to the relationship between levels of government in the nation-state, whether in a federation or a unitary state (Bevir, 2011: 468). Intergovernmental relations (IGR) occurs in all countries, both federal and unitary countries. However, the dimension that 
distinguishes it is the authority that is owned or called the "degree of decentralization" (Hendratno, 2009: 72).

Based on the above opinion, the analysis emphasizes the dimensions of all units, namely at the level/level of government in the Indonesian state system which consists of the government as the central government, provincial government, district government and village government regarding authority in mining matters by referring to Law No. 23 of 2014 concerning Regional Government. Relations between governments in this context involve all units in government which show the diversity of relationships between all governments. Indonesia as a unitary state has governmental areas that are spread out in various regions, both provinces and districts and villages according to the interpretation of the meaning of the 1945 Constitution. Furthermore, in this discussion section, the level of government will be explained in seeing the authority in gold mining management in Riau Province. the level / levels of government consist of the central government, provincial governments, district governments and village governments.

\section{Central Government}

As a government entity, the central government has the position of the highest government compared to other government entities in the Republic of Indonesia. Meanwhile, an autonomous region is not a stand-alone entity or a state within a state like in the most orthodox federal states, because Indonesia is a unitary state that does not allow a state within a state (Bhenyamin, 1993). The pattern of power sharing between the central government and regional governments is based on the principle of a unitary state but in the spirit of federalism. Where the type of power exercised by the central government is almost the same as that exercised by the central government in the federal state which includes foreign relations, defense and security, justice, monetary, religion and so on.

Furthermore, talking about mining affairs, based on Law Number 23 of 2014 concerning Regional Government in article 14 paragraph (1) it has been explained that the administration of energy and mineral resources affairs is divided between the central government and provincial regions. Referring to Law Number 23 of 2014 concerning Regional Government, in the mineral and coal sub-affairs, the central government has 11 powers after experiencing efficiency / simplification of authority from the previous regulation, namely 27 authorities. However, this means that the implementation of submineral and coal affairs cannot be separated from the authority of the central government as the highest authority holder of other autonomous regions. The 11 authorities possessed by the central government consist of: 
1. Determination of mining areas as part of the spatial layout of the national territory consisting of mining business areas, community mining areas and state reserves as well as special mining business areas.

2. Determination of metal mineral and coal mining business permits and special mining business license areas

3. Determination of non-metal mineral and rock mining business permits across provinces and sea areas of more than 12 miles

4. Issuance of mineral, metal, coal, non-metal mineral and rock mining business permits at:

a. Mining business license areas located across provinces

b. Mining business permit areas that have direct borders with other countries

c. The sea area is more than 12 miles

5. Issuance of mining business permits for foreign investment

6. Granting special mining business permits for minerals and coal

7. Giving registration of mining business licenses and determining the amount of production in each province for metal mineral and coal commodities

8. Issuance of mining business permits for special production operations for processing and refining whose mining commodities originate from other provincial areas outside the location of processing and refining or import facilities as well as for foreign investment.

9. Issuance of mining service business licenses and registered certificates for domestic investment and foreign investment whose business activities are carried out throughout the territory of Indonesia.

10.Determination of benchmark prices for metal minerals and coal

11.Management of mining inspectors and mining supervisory officials

Based on the authority possessed by the central government, the authority to determine mining business areas including community mining areas rests with the central government. This means that the central government has absolutely the right to determine mining areas as suitable locations for mining business activities including gold mining in Kuantan Singingi Regency, Riau Province. The determination of mining areas by the central government is based on a submission mechanism made by the local government to the central government through the draft regional regulations.

Apart from the authority as described above, matters relating to the guidance and supervision of the administration of functions by the regions, including matters relating to energy and mineral resources, are the responsibility of the central government in accordance with the contents of article 7 paragraph (1) of Law No. 23 of 2014 
concerning Regional Government. This means that the responsibility to carry out guidance, control, supervision and other tasks is the authority of the central government, which is represented by government officials who handle the fields in question.

Based on the authority possessed by the central government, mining affairs are actually the task of the Ministry of Energy and Mineral Resources as regulated in a Ministerial Regulation. The legal basis for the implementation of these duties and functions is regulated in the Regulation of the Minister of Energy and Mineral Resources (ESDM) Number 13 of 2016 concerning the Organization and Work Procedure of the Ministry of Energy and Mineral Resources that the Directorate General of Mineral and Coal is under and responsible to the Minister. The duties and functions of the directorate general of minerals and coal are as follows:

1. Formulation of policies in the field of development, control and supervision of business, engineering, work safety, environment and construction of certain facilities and infrastructure, as well as management of non-tax state revenues in the mineral and coal sector in accordance with statutory regulations;

2. To implement policies in the field of development, control and supervision of business, engineering, work safety, environment and construction of certain facilities and infrastructure, as well as management of non-tax state revenues in the mineral and coal sector in accordance with statutory regulations;

3. Formulation of norms, standards, procedures and criteria in the field of development, control and supervision of business, engineering, work safety, environment and construction of certain facilities and infrastructure, as well as management of non-tax state revenues in the mineral and coal sector in accordance with statutory regulations. -invitation;

4. To provide technical guidance and supervision in the field of development, control and supervision of business, engineering, work safety, environment and construction of certain facilities and infrastructure, as well as the management of non-tax state revenues in the mineral and coal sector in accordance with statutory regulations;

5. To carry out evaluation and reporting in the field of development, control and supervision of business activities, engineering, work safety, environment, and the construction of certain facilities and infrastructure, as well as management of non-tax state revenues in the mineral and coal sector in accordance with statutory regulations;

6. To carry out the administration of the directorate general of minerals and coal;

7. Implementation of other functions assigned by the minister. 
Based on the authority possessed by the central government, the implementation of mineral and coal activities is an extension of and is under the Minister of Energy and Mineral Resources in carrying out government affairs related to the above tasks and functions. Nonetheless, further regulations regarding the administration of affairs in the mining sector are also regulated based on the Law on Regional Government, especially in article 14 paragraph (1) which divides these functions between the central government and the provincial government.

\section{Provincial Government}

The mandate of Law Number 23 of 2014 concerning Regional Government is directed at accelerating the realization of community welfare through improved services, empowerment and community participation. The efficiency and effectiveness of regional government administration needs to be improved by paying more attention to aspects of the relationship between the central and regional governments and between regions as well as the opportunities and challenges of global competition in the unified state governance system.

The provincial government, apart from having the status of a region, is also an administrative area and is the working area of the Governor as an extension of the central government as well as a working area in carrying out general government affairs in provincial areas. In its position as an administrative region that carries out the functions of the deconcentration authority, the provincial government plays an important role as the adhesive element of the Unitary State of the Republic of Indonesia. This is also interpreted as an effort to maintain and strengthen the unity and integrity of the nation in order to increase empowerment, foster initiative, community creativity and national awareness. As the representative of the central government, the governor has the role of maintaining harmony between the central government and the regions to encourage the acceleration of the successful implementation of decentralization in the districts / cities (Kartiwa and Nugraha, 2012: 66).

Furthermore, in carrying out general government affairs in the provincial area, the explanation of Law Number 23 of 2014 concerning Regional Government states that the province has the authority in matters of mineral and coal sub-affairs. Where in fact this authority has been simplified as a follow-up to the principle of efficiency, from 18 authorities to 7 authorities regarding sub-affairs of minerals and coal. The explanation above emphasizes that the authority related to the issuance of metal and non-metal mineral, rock and coal mining business permits in regional mining business permits located within 1 (one) provincial area up to 12 miles of sea territory is the full authority of the government. province. 
Meanwhile, gold mining in Kuantan Singingi Regency is a mining area which is the responsibility of the Riau Provincial Government to manage it and issue mining business permits for both metal and nonmetallic minerals. However, what happens is that the development of gold mining activities that do not have a business license is used as a livelihood commodity by the people in Kuantan Singingi Regency, causing environmental disruption and damage to community plantations around the mining location.

Based on the authority possessed by the Riau Provincial government, the implementation of gold mining management and issuance of mining permits is actually the responsibility of the provincial government with the scale of the people's mining area (WPR). Changes in authority regarding mining based on Law Number 23 of 2014 concerning Regional Government automatically also changes the organizational structure of the government at the provincial level, especially at the Riau Energy and Mineral Resources Office as regulated under the Riau Governor Regulation Number 48 of 2018 concerning Position, Organizational Structure, Duties and Functions, as well as Work Procedures for the Department of Energy and Mineral Resources of Riau Province.

Furthermore, with the issuance of the Regional Government Law which grants mining authority to the provincial government, it can be said that the implementation of authority related to gold mining is actually the task of the provincial government through the Riau Province Energy and Mineral Resources Office. Meanwhile, in terms of supervision, the ESDM office adheres to Article 3 of Government Regulation No.23/2010 concerning the Implementation of Mineral and Coal Mining Business Activities that mining business activities are based on mining business permits. So it is clear that PETI gold mining is illegal mining. Even so, there is still an inventory by the Riau Province ESDM office. Based on the criminal provisions of article 158 in Law Number 4 of 2009 concerning Mineral and Coal Mining that those who carry out mining activities without having a mining permit will be subject to sanctions, ESDM collaborates with the security forces to resolve the issue.

The implementation of mineral and coal mining business activities as regulated in Government Regulation Number 23 of 2010 concerning the Implementation of Mineral and Coal Mining Business Activities is intended to implement policies prioritizing the use of minerals and/or coal for domestic interests. This is a manifestation of the mandate of the 1945 Constitution Article 33 paragraph 3 that all natural wealth found on Indonesian soil is a state asset that is intended for the interests of the people.

On the other hand, the phenomenon of illegal gold mining practices in Kuantan 
Singingi Regency has occurred since 2009 by local communities and also immigrants who are employed by capital owners to carry out mining activities in exchange for instant and promising income so that the equipment used is not up to standard and is dangerous. The use of mining equipment using "dompeng" machines (the term local residents refer to equipment used for mining) and the use of hazardous substances such as mercury have actually only been practiced for the last ten years by miners with the aim of obtaining mining products relatively quickly compared to using this method. traditional namely by panning. For the provincial government itself, as the owner of the mining sector, mining activities carried out by the local community are alternative livelihoods apart from plantations and fishermen. However, if the process of obtaining it uses dangerous substances and equipment, it will have serious effects on the community, especially those who live around the river. In addition, abrasion is caused by excavation activities that do not comply with work safety standards.

Serious problems ranging from environmental pollution, social and health problems can occur due to PETI activities that do not get a firm response from the Riau Provincial government as the holder of authority. The involvement of the active role of the community and the efforts of the Riau Province government as the main actor is needed not only in the policy aspect, but also in controlling pollution and environmental damage due to PETI activities. The emergence of unlicensed gold mining activities (PETI) is difficult to avoid because it is related to the need for mining products to support life. The people of Kuantan Singingi Regency with economic limitations encourage them to manage their own mineral (gold) resources in their area to improve the standard of living and economy of their group, without realizing that this will have a negative impact on the region.

Referring to the provisions of the Regulation of the Minister of Energy and Mineral Resources Number 26 of 2018 concerning Implementation of Good Principles and Supervision of Mineral and Coal Mining, that the implementation of mining business management is carried out by the minister or governor in accordance with their respective authority. Apart from that, the minister supervises the implementation of mining business management carried out by the governor, where supervision of the implementation of mining business management carried out by the governor includes the determination and granting of non-metal mineral mining business permit areas (WIUP) and mining business permit areas (WIUP). rocks, granting mining business permit areas (WIUP) for metal minerals and WIUP of coal, issuing public mining permits (IPR) and issuing mining business permits (IUP). 
The Riau Provincial Government through the Department of Energy and Mineral Resources in 2019 made an initiation with the Riau Provincial DPRD regarding the submission of a draft regional regulation related to community mining, but this has not received a serious response from the DPRD. The discussion on the draft regional regulation on community mining cannot yet be carried out considering that priority programs are prioritized for other activities. It is important that the draft regional regulation on community mining be discussed and stipulated in managing gold mining activities in Riau as a legal umbrella and guidance in the implementation of mining activities in Riau Province.

Meanwhile, the implementation of authority in the issuance of mining business permits is carried out by the Riau Provincial government through the One Stop Investment and Integrated Services Service (DPMPTSP) which coordinates with the Riau Energy and Mineral Resources Office if there is a request for mining permit processing. The application mechanism is accepted by the DPMPTSP office which is then sent to the ESDM office to ask the field technical personnel to carry out surveys and technical tests with the financing burden borne by the DPMPTSP office. Applications submitted by prospective mining business actors will be accepted if they comply with predetermined requirements, one of which is to obtain a recommendation from the respective regional head.

\section{District Government}

The district government is an autonomous region as well as an administrative area as the regent's working area in carrying out general government affairs in the regency area. District government is one of the government units within the territory of the Republic of Indonesia. Based on Law Number 23 of 2014 concerning Regional Government, regency regional governments no longer have the authority to sub-affairs minerals and coal, because this authority has been withdrawn to the provincial government for reasons of efficiency / simplification of authority. This means that the district government no longer has the responsibility to carry out sub-affairs of minerals and coal. Meanwhile, what can be described here is that the gold mining area is actually in the Kuantan Singingi Regency area, while the mining authority rests with the Riau Provincial Government. As for things that are still a polemic in the community in the Kuantan Singingi Regency area, especially those who live around the gold mining area without a permit, namely the impact of environmental pollution and their livelihood activities which are disrupted due to unmanaged gold mining waste (PETI). well. Other problems that arise are social problems, health problems, damage to land, which previously the community used 
the land for agricultural or plantation activities will no longer be able to use the land as usual, because it will take a long time to repair damaged soil.

In fact, the efforts made by the government of both Riau Province and Kuantan Singingi Regency are concrete steps that need to be coordinated in an effort to overcome the problem of mining that does not have a permit that can harm the area as well as the local community affected by the illegal mining waste. Although the authority for mining management rests with the Riau provincial government, that does not mean that this does not necessarily need the attention of the Kuantan Singingi Regency Government. Therefore, the Kuantan Singingi Regency Government still needs to coordinate with the Riau Provincial Government to overcome this illegal mining problem because it involves the welfare of the local community.

Furthermore, with regard to mining authority, after the enactment of Law Number 23 of 2014 concerning Regional Government for the Kuantan Singingi Regency Government, there was indeed a significant change, especially in the change in the organizational structure of the district apparatus after the withdrawal of mining authority from the Riau Provincial Government.

Concrete efforts to prevent the development of PETI that have been carried out by the Kuantan Singingi Regency
Government in general are also through the environmental service which is discussed in the regional leadership communication forum (forkompinda) which consists of KAPOLRES, DANDIM, KAJARI, Courts and Local Governments, but until now it has not showed significant results overall. Among the persuasive efforts made, namely through the socialization of the negative impacts of PETI activities on the environment. Apart from that, data collection was also conducted on the location of PETI, the number of PETI actors, the scale of PETI and so on in order to know the distribution and impact of PETI. Even though they have conducted socialization and data collection on PETI actors, this does not immediately stop PETI activities, this is due to the lack of awareness of PETI actors.

Various efforts to tackle gold mining without a permit (PETI) were also carried out by controlling PETI actors. This is intended to stop sources of pollution and/or environmental damage. The control was carried out by the local police in collaboration with the Kuantan Singingi District Police. In controlling, the police also confiscated equipment for PETI activities in the form of a "dompeng" machine as a tool for mending (local term). Even though the control has been carried out, the facts on the ground show that PETI activities are still operating due to the absence of strict criminal sanctions. Meanwhile, based on Law Number 04 of 2009 concerning Mineral and Coal Mining Article 158, it has been stated that 
every person conducting mining business without a permit will be sentenced to a maximum imprisonment of 10 (ten) years and a maximum fine of ten billion rupiah. Weak law enforcement is also what encourages perpetrators to continue to carry out their activities repeatedly which do not appear to have a deterrent effect on them. However, efforts to control by conducting raids on illegal gold mining actors are often carried out as a repressive step to overcome the PETI problem. The data on the findings of the disclosure of PETI by the Kuantan Singingi Police can be seen in the table below:

Table.1 Data on Disclosure of PETI Crime in Kuantan Singingi Regency 2014 to 2019.

\begin{tabular}{|l|l|c|c|c|c|c|c|}
\hline NO & $\begin{array}{l}\text { SUB- } \\
\text { DISTRI } \\
\text { CT }\end{array}$ & $\begin{array}{c}\text { Year } \\
2014\end{array}$ & $\begin{array}{c}\text { Year } \\
2015\end{array}$ & Year & Year & Year & Year \\
2017 & 2018 & 2019 \\
\hline 1 & $\begin{array}{l}\text { Ktn } \\
\text { Tengah }\end{array}$ & 4 & 5 & 6 & 9 & 3 & 2 \\
\hline 2 & $\begin{array}{l}\text { Ktn } \\
\text { Mudik }\end{array}$ & 0 & 3 & 5 & 7 & 1 & - \\
\hline 3 & $\begin{array}{l}\text { Gunung } \\
\text { Toar }\end{array}$ & 3 & - & 3 & 2 & - & - \\
\hline 4 & $\begin{array}{l}\text { Hulu } \\
\text { Kuantan }\end{array}$ & - & 1 & 1 & 1 & 1 & - \\
\hline 5 & Benai & - & - & - & - & - & - \\
\hline 6 & $\begin{array}{l}\text { Sentajo } \\
\text { Raya }\end{array}$ & - & 1 & 2 & - & 1 & - \\
\hline 7 & Pangean & - & - & 1 & 5 & - & - \\
\hline 8 & $\begin{array}{l}\text { Logas } \\
\text { Tnh } \\
\text { Darat }\end{array}$ & - & - & - & 2 & 1 & - \\
\hline 9 & $\begin{array}{l}\text { Kuantan } \\
\text { Hilir }\end{array}$ & - & - & 3 & 1 & - & - \\
\hline 10 & $\begin{array}{l}\text { Ktn } \\
\text { Hilir }\end{array}$ & - & - & - & 1 & - & - \\
\hline & & & & & & \\
\hline
\end{tabular}

\begin{tabular}{|c|c|c|c|c|c|c|c|}
\hline & $\begin{array}{l}\text { Seberan } \\
\mathrm{g}\end{array}$ & & & & & & \\
\hline 11 & Singingi & 3 & 4 & 9 & 11 & 8 & 1 \\
\hline 12 & $\begin{array}{l}\text { Singingi } \\
\text { Hilir }\end{array}$ & 2 & - & 4 & 5 & 2 & - \\
\hline 13 & Inuman & - & - & - & - & - & - \\
\hline 14 & Cerenti & - & - & 1 & 1 & - & - \\
\hline 15 & $\begin{array}{l}\text { Pucuk } \\
\text { Rantau }\end{array}$ & - & - & - & - & - & - \\
\hline & Total & 12 & 14 & 35 & 45 & 17 & 3 \\
\hline
\end{tabular}

Source: Polres Kuantan Singingi, 2020

The data above shows that PETI criminal cases occur every year, this can be seen from the presence of PETI perpetrators who carry out illegal mining activities. Based on information from the Kuantan Singingi Police, the number of cases included in the data above are only activities that were carried out at the time of the raid/arrest of the perpetrator who was at the scene of the incident. Meanwhile, those that were carried out during the arrest / raid, but the owners and perpetrators of PETI who were not at the scene of the case were not included in the data above and were not counted as cases. This means that the number of cases and illegal mining actors who have not been caught is more than the number recorded by the police.

\section{Village Government}

Village is the lowest structure of government entities in the government structure in Indonesia as a unitary state. The strengthening of the value of complete autonomy is actually seen in the village 
government structure as an inseparable part of the Indonesian government structure. As an autonomous region, the village actually has the independence to maintain the customs and habits agreed by the local community as a legal community unit to regulate and manage its own governmental affairs. This means that the state mandates villages to maintain traditional values that are recognized and respected in the Indonesian government system as a follow-up to the goal for the welfare of rural communities.

The village is the lowest unit of the government structure that is in the district / city as an integral part of a country that carries out government affairs based on statutory regulations. In carrying out government affairs, the village is led by a Village Head whose job is to serve the interests of the village community. Based on Law Number 6 of 2014 concerning Villages, especially Article 7, it is stated that the village needs to be structured with the aim of realizing the effectiveness of village administration, accelerating the improvement of the welfare of rural communities, accelerating the improvement of public service quality, improving the quality of village governance, increasing competitiveness. village.

The village in Kuantan Singingi Regency, like other villages throughout Indonesia, carries out governance based on origins and customs as well as local wisdom that is recognized in the Indonesian government system. Furthermore, the development of unlicensed gold mining activities (PETI) in Kuantan Singingi Regency is spread across several villages within the Kuantan Singingi Regency area. Most of the villages in the Kuantan Singingi Regency area have gold mining locations that are illegally carried out by local communities, both individually and in groups. This of course requires special attention by local government officials in this case including the involvement of the village head and his apparatus as the government element closest to the community to be able to resolve the problems in question. In fact, some of the community involved as PETI actors gave an answer that PETI activities were carried out in order to sustain life. Economic hardship is one of the reasons people are compelled to carry out these prohibited activities.

Most of the community mendompeng (the term local people who work as illegal gold miners). The proliferation of "dompeng" activities began in 2011 which then experienced a significant increase in 2014 to 2016 with the number of machines reaching 30 dompeng machines for each village. How not in a day gold miners get 1 to 2 grams of gold per day with the amount of fuel needed around 35-40 liters. Meanwhile, workers for one dompeng machine consist of 4 to 6 miners, most of whom are not local residents but are imported from outside Sumatra, as the majority come from the island of Java. What is 
equally alarming is that there are several village heads in Kuansing Regency who are involved as owners of capital in PETI activities. This condition actually makes the PETI problem difficult to eradicate, where there is the involvement of village government officials who take part in these unauthorized activities.

When viewed from its existence, there are those who are driving the presence of PETI in Kuantan Singingi Regency, namely because of several factors, one of which is economic factors which are caused by limited employment opportunities and business opportunities according to the level of expertise or skills of the lower community. Lack of awareness in various matters, both environmental, health and lack of knowledge and skills, as well as the existence of third parties who take advantage of opportunities for certain purposes, namely funders (cukong), unscrupulous officials who take advantage and the economic crisis which has an impact on the increase in the price of living necessities so that give birth to unemployment, especially from the lower class of society.

The presence of laws and regulations that specifically regulate life in the community, such as the law on regional government and the law on mining, is a supporting factor for solving a problem. Even so, this can also be the reason for the development of PETI activities due to the public's ignorance of the prevailing laws and regulations in the mining sector as well as weaknesses in the enforcement of mining laws and regulations, which among others is reflected in the lack of partiality to the interests of the wider community and There is no warning against legal or licensed mining that does not take advantage of its business area (idle land), as well as the occurrence of weaknesses in law enforcement and supervision.

Based on the results of the study, information was obtained that in most of the villages in Kuantan Singingi Regency there were unlicensed gold mining locations carried out by the local community which caused pollution to the river flow. Meanwhile, most of the village heads are aware of illegal mining activities in their village, but due to community economic reasons, the village government has not been able to fully take firm action against PETI actors. This is due to the needs of people who depend on rubber and oil palm agricultural commodities. So that with the decline in income from this sector, people shift their livelihoods to illegal mining activities.

\section{CONCLUSION}

Based on the results of the research, it was concluded that by simplifying the mining authority that resided with the provincial government, it was not immediately possible to stop PETI activities which were scattered in most villages in Kuantan Singingi Regency. 
Involvement and cooperation from elements of government administration both at the provincial to village levels are needed to manage mining activities so that they can be managed into community mining in accordance with the mandate of Law Number 23 of 2014 concerning Regional Government and Law Number 4 of 2009 concerning Mineral and Coal Mining. Furthermore, the simplification of authority in mining matters based on Law Number 23 of 2014 concerning Regional Government affirms the authority of the Riau Provincial Government in carrying out mining affairs by involving the Kuantan Singingi Regency Government in a coordinative manner to manage gold mining in order to improve the welfare of local communities through legal community mining activities. Basically, the village head as the ruler in his area actually knows the activities carried out by the community, but for economic reasons that makes the village head unable to take firm action against the illegal gold miner. Meanwhile, from the results of the interview, the researchers also found that the village government itself did not receive mandatory payments on a regular basis by the owners of the capital or the illegal gold mining business, even though it was another form of reward, namely that they still made contributions in material and in-kind when there are certain events in the village concerned. This means that the village government as the lowest government structure participates in indirectly inviting illegal mining actors to carry out their activities in the village concerned.

\section{REFERENCES}

[1] Amrusyi, Fahmi. (1987). Otonomi Dalam Negara Kesatuan, dalam Abdurrahman (editor), Beberapa Pemikiran Tentang Otonomi Daerah, Media Sarana Press, Jakarta.

[2] Bevir, M. (Ed). 2011. The SAGE Handbook of Public Policy. Routledge. USA and Kanada

[3] Cresswell, John. W. (2016). Research design: qualitative, quantitative, and mixed methods approaches. Sage publications.

[4] Daud Busroh, Abu. (1990). Ilmu Negara, Cetakan Pertama, Bumi Aksara, Jakarta.

[5] Hendratno, Edi. (2009). Negara Kesatuan, Desentralisasi dan Federalisme, Graha Ilmu, Yogyakarta.

[6] Hossein, Bhenyamin. (1993). Beberapa faktor yang mempengaruhi besarnya otonomi daerah tingkat II, suatu kajian desentralisasi dan otonomi daerah dari segi ilmu administrasi negara, disertasi UI, Jakarta.

[7] Huda, Ni'matul. (2014). Desentralisasi Asimetris dalam NKRI. Jurnal Administrasi Pemerintahan Daerah, Volume I, Edisi Kedua, H.9, dalam Dr. Ni'matul Huda, SH,M.Hum, , Nusa Media, Bandung.

[8] Isjwara, Fred. (1974) . Pengantar Ilmu Politik, Cetakan Kelima, Binacipta, Bandung.

[9] Kartiwa, A dan Nugraha. (2012). Mengelola Kewenangan Pemerintahan. Lepsindo, Bandung.

[10] Kencana Syafiie, Inu. (2010). Pengantar ilmu pemerintahan. Refika Aditama, Jakarta.

[11] Nurmayani. (2009). Hukum Administrasi Daerah. Universitas Lampung Bandar lampung.

[12] Ridwan HR. (2013). Hukum Administrasi Negara. PT Raja Grafindo Persada. Jakarta. 
[13] Syafrudin, Ateng. (2000). Menuju Penyelenggaraan Pemerintahan Negara yang Bersih dan Bertanggung Jawab, Jurnal Pro Justisia Edisi IV, ( Bandung, Universitas Parahyangan).

[14] Wasistiono, S. (2003). Kapita Selekta Manajemen Pemerintahan Daerah. Fokusmedia.

[15] Wright, D. S. (1975). Intergovernmental relations and policy choice. Publius, 5(4), 124

[16] Undang-Undang Nomor 4 Tahun 2009 tentang Pertambangan Mineral dan Batubara

[17] Undang-Undang Nomor 23 Tahun 2014 tentang Pemerintahan Daerah

[18] Undang-Undang Nomor 6 Tahun 2014 tentang Desa.

[19] Peraturan Pemerintah Nomor 55 Tahun 2010 tentang Pembinaan dan Pengawasan Penyelenggaraan Pengelolaan Usaha Pertambangan Mineral dan Batubara.

[20] Peraturan Menteri Energi dan Sumber Daya Mineral (ESDM) Nomor 13 tahun 2016 tentang Organisasi dan Tata Kerja Kementerian Energi dan Sumber Daya Mineral.

[21] Peraturan Menteri Energi dan Sumber Daya Mineral Republik Indonesia Nomor 11 Tahun 2018 tentang Tata Cara Pemberian Wilayah, Perizinan dan Pelaporan pada Kegiatan Usaha Pertambangan Mineral dan Batubara.

[22] Peraturan Menteri Energi dan Sumber Daya Mineral Nomor 26 Tahun 2018 Tentang Pelaksanaan Kaidah yang Baik dan Pengawasan Pertambangan Mineral dan Batubara.

[23] Peraturan Daerah Kabupaten Kuantan Singingi Nomor 4 Tahun 2016 tentang pembentukan dan susunan perangkat daerah Kabupaten Kuantan Singingi khususnya bab II tentang Pembentukan dan Susunan Perangkat Derah pasal 3 ayat 1 pada point D yang tidak terdapat Dinas ESDM sebagai bagian susunan perangkat daerah di Kabupaten Kuantan Singingi. 